\title{
Call for Submissions
}

\author{
Special Guest Edited Issue of Dance Research Journal \\ Guest Editor: Nadine George-Graves
}

\section{ARMS AKIMBO: BLACK WOMEN CHOREOGRAPHING SOCIAL CHANGE}

Black women have been at the forefront of era-shifting social change. Black women have been the targets of manufactured labels meant to control and destroy them both psychically and politically. In the midst of these landscapes, black women have challenged dominant intellectual history and ideology, sometimes by speaking loudly from the mouth of the dragon and sometimes by putting their bodies on the line. The orchestration of social change is a choreography that often relies on negotiations in terms of race, class and gender. But what happens when we depend on black women to move movements? What do we demand from the strong, black, female body? What "power" is tapped, deployed, erased, ignored and/or exhausted? How are conversations navigated, pushed, short-handed and/or silenced? What happens to vulnerability, tenderness and mental health? What sustains? What depletes? And what role does dance/choreography play in effecting change at these junctures?

Dance has always been more than choreography. Movement has always moved minds as well as bodies. Black women in dance traverse myriad aesthetics, skills, emotions, politics, epistemologies and identities to produce vast and complex performance histories.

This special issue seeks to take up some of the most important conversations about the work of black women in and through dance. It also aims to push theoretical debates in critical race studies, critical gender studies and critical dance studies. Recognizing different international definitions of "black," broadened contemporary understandings about gender identity, a wide range of dance aesthetics on and off stage, and debates around the efficacy of social change movements, this special issue seeks to interrogate the international history of and continued look to "blackness" and "femaleness" in processes of change through the performing arts: social justice, equity, inclusion, etc.

Possible areas of focus include: the choreography of particular artists (early career to established), broad trends in aesthetics influenced by and influencing societal debates, historical contexts and contemporary debates, affect theory (e.g. black female joy, rage, desire, respect, power, intimacy), sexualities and gender, queer theory, efficacy and social change, afro-futurism, afro-pessimism, afropunk, transnational black feminism and womanism, black girlhood, philosophy, theory and intellectual history, nation-making, solidarity/community-building, the radical-radical politics, radical pleasure, the carceral, the protest, activism as choreography.

Final deadline for submissions: December 30, 2019

The editor encourages contributions from scholars, artists and artist/scholars. Approximate length of scholarly articles: 6000 words (not including references). Less formal engagements (e.g. interviews, "an artist writes"), are possible in shorter formats.

For information about submission, visit: https://dancestudiesassociation.org/drj-guidelines

Enquiries welcome: Nadine George-Graves (george.946@osu.edu) 


\section{Drama and}

\section{Theatre}

Books and Journals from Cambridge University Press

We are the world's leading publisher in theatre and drama books and journals, with a wide-ranging coverage of the discipline.

Our publishing encompasses theatre history, performance theory and studies, Shakespeare, regional drama and popular theatre.

We publish the journals of the American Society for Theatre Research, the Congress on Research in Dance, and the International Federation for Theatre Research, and provide books for all areas of the market, including university libraries, scholars, students, and theatre enthusiasts.

For further details visit:

\section{cambridge.org/core-theatre}

\section{Çambridge Core}


Dance Research Journal (DRJ) is indexed and abstracted by the following databases: Academic Search Elite, Academic Search Premier, Dance Collection Catalog of The New York Public Library, Expanded Academic Index, Humaities Index, Index to Dance Periodicals, International Index to Performing Arts, Proquest and SPORTDiscus. Complete articles are available on the Web through UMI. Past issues (through 2000) are indexed in the CD-ROM, Dance: Current Awareness Bulletin. Back issues of DRJ are available on JSTOR.

The Dance Studies Association (DSA) is an interdisciplinary organization with an open, international membership. Its purposes are I) to encourange research in all aspects of dance, including its related fields; 2) to foster the exchange of ideas, resources, and methodologies through publications, international and regional conferences, and workshops; 3 ) to promote the accessibility of research materials.

DSA is a nonprofit, tax-exempt organization. Copies of the DSA financial and operating report, filed with the state of New York, are availale upon written request from the New York State Board of Social Welfare, Charities Registration Section, Office Tower, Empire State Plaza, Albany, NY 12242.
Please see http://www.dancestudiesassociation. org for information about annual memberships in Dance Studies Association, which includes Dance Research Journal (3 issues per year), Studies in Dance History (one monograph per year), and Conversations Across the Field of Dance (one issue per year), in addition to other member benefits. Institutional subscription rates for 2019 are given below.

$\begin{array}{lcc} & \begin{array}{c}\text { North America } \\ \text { (USA, Canada, } \\ \text { Mexico) }\end{array} & \begin{array}{c}\text { Outside } \\ \text { North } \\ \text { America }\end{array} \\ & \$ 272 & \mathfrak{E} 171 \\ \begin{array}{c}\text { Institutions print } \\ \text { and electronic: }\end{array} & \$ 196 & \mathfrak{E} 122 \\ \begin{array}{c}\text { Institutions } \\ \text { electronic only: }\end{array} & & \mathfrak{E} 153 \\ \begin{array}{c}\text { Institutions print } \\ \text { only: }\end{array} & \$ 247 & \\ \begin{array}{c}\text { Association Paid } \\ \text { Member rate }\end{array} & \mathfrak{L} / \$ 71 & \\ & & \end{array}$




\section{Dance Research JOURNAL}

\section{Forthcoming Articles in DRJ 51/2 (August 2019)}

Articles

Aesthetic Strategies of Trance-gression: The Politics of Bodily Scenes of Ecstasy

Sabine Huschka

Orientalized Aztecs: Observations on the Americanization of Theatrical Dance

Mitch Snow

Embodied Knowledge as Revolutionary Dance: Representations of Cuban Modern Dance in Alma Guillermoprieto's Dancing with Cuba Rachel Oriol

A Changing Focus: The Evolution of Irish Step Dancing Competitions in Australia Jeanette Mollenhauer 